\title{
Research on the Practice Mode of Ideological and Political Education in Colleges and Universities
}

\author{
Wei Liu \\ Liaoning Jianzhu Vocational College, Liaoyang, Liaoning, 111000
}

Keywords: practice mode; ideological and political education; colleges and universities

\begin{abstract}
Ideological and political education is the most important task in colleges and universities, and it concerns the health and sustainable development of colleges and universities. However, at this stage, the malpractices of the ideological and political education model in traditional colleges and universities have become increasingly prominent, hindering the orderly development of ideological and political education. Therefore, efforts should be made to construct a holistic process of ideological and political education to guide the practice of ideological and political education in colleges and universities. This paper outlines the connotation of ideological and political education model in all aspects, and systematically discusses the construction of ideological and political education model in all aspects.
\end{abstract}

\section{Introduction}

In recent years, the theoretical circle has discussed the mode of ideological and political education in colleges. It is widely believed that there are mainly two types of ideological and political education work modes in history: the indoctrination mode and the infiltration mode. Under the new situation, there are mainly three kinds of ideological and political education models in Chinese universities: image education model, interactive education model, and online education model. According to the different directions of communication, some scholars divide the mode of communication into two types, horizontal and vertical. The vertical interaction mode can be further divided into: network interaction mode that advances with the times; face-to-face interaction mode; influence interaction mode Self-education, self-improving communication and interaction mode. Some scholars have studied the tactics and methods of network ideological and political education, and have described three basic modes of carrying out college students' ideological and political education based on the campus network: content center model, media center model, and user center model. The research on the classification of ideological and political education model in colleges has gradually focused on the micro level, and has important reference value for the research on model innovation.

\section{The Concept of Ideological and Political Education in Colleges and Universities in all Aspects}

In order to meet the changing needs of the times, colleges are actively exploring new ideological and political education modes and approaches. For example, some colleges learn from the advanced experience of foreign countries and proceed from their own realities to explore new modes of "education"; some universities also adhere to the combination of theory and practice to create the "education" of the unity of life and study. new environment. However, the construction of the ideological and political education model in colleges is a systematic and complex project. It requires advanced construction concepts, perfect operating mechanisms, and sound supporting facilities to provide guarantees. Under such circumstances, the concept of an ideological and political education model in all aspects of the entire process has emerged. From the perspective of etymology, "patterns" come from general scientific philosophy or scientific methods. Nowadays, the connotation of the "pattern" has been continuously enriched and the extension has been continuously extended, covering all walks of life and many fields. The definition of "pattern" in 
Modern Chinese Dictionary is defined as follows: "The standard form of a thing or the standard style that people can follow."[1] Based on this, the author believes that the ideological and political education model in colleges It refers to the guidance of scientific and advanced ideological and political education theory, and the design and construction of comprehensive theoretical models and practical paradigms suitable for the practice of ideological and political education in colleges based on the practical needs of college students' ideological and political education. It can be seen that the ideological and political education model in colleges includes two levels: First, there must be scientific and advanced ideological and political education theories. If this condition is lacking, the ideological and political education practice in institutions of higher learning will not create any sustainability. The second is to create a comprehensive theoretical model and a practical paradigm, which shows that the ideological and political education model in colleges is an organic education system, education philosophy, education goals, education content, education methods, education vectors, etc. All of them are specific construction content.

\section{Construction of Ideological and Political Education Mode in Colleges and Universities}

In terms of innovation in ideological and political education in colleges, the ideological and political education model that builds the full range of the entire process plays an important role in the development of the system. It mainly carries out the reform and innovation of ideological and political education in colleges from the aspects of the construction of the curriculum system, the construction of the entrance system, the construction of the teaching environment system, and the construction of the practical system, and finally realizes the fundamental goal of strengthening the ideological and political education in colleges.

The beginning of ideological and political education throughout the entire process. From the beginning of ideological and political education for college students, the beginning of a good ideological and political education is often more influential than the strengthening of ideological and political education itself. It has inspired students' thinking through a good beginning of education, which has laid a solid foundation for ideological and political education in colleges. Foundation. The beginning of ideological and political education in all aspects of the whole process is centered on the student's education system, and through the continuous enhancement of students' ideological and political education, the students can adapt to the university's living and learning environment as quickly as possible, and the process of cultivating the comprehensive abilities of university students [4]. With the emphasis on education in our country and the changes of college students' ideas and concepts, entrance education has become the first important education for college students after entering college, and it occupies an important proportion in the ideological and political education of college students. In the actual teaching process, the contents of the education for enrollment need to be further expanded, and the forms of teaching need to be further enriched, so as to construct a comprehensive and rich system of college entrance education. Admission education should be based on the student-centered principle, ideological education in the aspect of moral education and behavioral morality, and ultimately achieve the fundamental goal of ideological and political education in colleges. The purpose of carrying out all-round ideological and political education in the whole process is to cultivate a group of high-quality college students who are open-minded, highly ethical, and love to learn. In addition, improving the theoretical knowledge and practical ability of ideological and political teachers and taking on the burden of ideological and political education are prerequisites for carrying out ideological and political education in colleges. It highlights the characteristics of the "all-round and full-process" education work, and continuously enriches the expansion of the organizational system, system system, and activity system in the entrance education. Staff must continue to improve and supplement the organizational system in the education system. It requires detailed consideration and deployment in the formulation of education goals, forms of education, and content of education. This will become an important guarantee for student follow-up management. In addition, schools should also establish an institutional system in the education system to provide support for the completion of all tasks in the education process. In addition, the staff should also increase the activity system, carry 
out a number of ideological and political education activities on various topics on a regular basis, improve the students' understanding of ideological and political education through the influence of various activities, and make the work of ideological and political education in universities different. Time, different occasions to achieve a comprehensive education for students.

All-round ideological and political education courses. The curriculum system of ideological and political education in all aspects of the whole process refers to the ideological and political education curriculum system centered on ideological and political theory courses, students' professional courses and other courses. The reasons for forming such a teaching system are: On the one hand, the ideological and political education in colleges is a complex teaching project. It is impossible to rely solely on ideological and political theory courses to improve students' ideological and political understanding. The curriculum system of ideological and political education in the process has improved the ideological and political education of college students from all aspects and links. On the other hand, students have different majors in their studies. Professional courses are the main courses for students to learn. Therefore, it is particularly important to integrate the ideological and political education work into the learning process of the students' professional courses, and the ideological and political education functions can be fully utilized [5]. We will include ideological and political education indicators in the evaluation system of ideological and political education work, and establish a sound ideological and political education curriculum system. The curriculum education system of ideological and political education in all aspects of the whole process is to conduct a comprehensive excavation of the elements of ideological and political education in professional education, and to establish a systematic and complete ideological and political education system. Therefore, the inclusion of the evaluation of ideological and political education work in the evaluation system of professional courses can not only improve students' understanding of ideological and political education, but also have a positive effect on improving students' professional development. Focusing on the teaching of ideological and political theory courses, we will continue to improve the effectiveness of ideological and political education. If we want to improve the ideological and political education in colleges and realize the goal of education, we must increase the reform of the ideological and political education theory curriculum, and innovate the teaching model and curriculum system. In addition, we must continue to seek connections between ideological and political theory courses and student professional courses, and actively construct a ideological and political education curriculum system that is based on ideological and political theory courses, students' professional courses, and other courses. The whole process of ideological and political education in practice. Like classroom teaching, extracurricular practice is also an important channel for ideological and political education in colleges. The extra-curricular practice mentioned here includes many aspects such as the practice of school activities, social practice outside the school, and the teaching of curriculum practice. However, no matter what form of education practice is adopted, it is imperative to dig deeper into the ideological and political education content under the extracurricular practice environment in order to fully reflect the connotation and essence of ideological and political education. Innovate social practice forms, reform theoretical teaching practice, and construct effective education practice systems. In the process of educational practice, we must pay attention to the innovation of teaching philosophy, teaching content, and teaching methods, so as to enrich the content of practical teaching and increase the actual effect of practical teaching. At the same time, we must emphasize scientific planning and design, and deepen students' understanding and grasp of theoretical knowledge through practical experience. Only in this way can we truly guarantee the authenticity and effectiveness of the ideological and political education practice model. Examine daily education management function, improve the practical teaching assessment mechanism, and enhance the continuity of practice teaching. The ideological and political education model in all aspects of the whole process advocates the need to integrate practical teaching with daily student management, seek new ideological and political education content in daily student management, and promote ideological and political education to promote the development of students' daily management career. . In addition, in the process of practical teaching, it is necessary to establish and improve the 
evaluation and guarantee mechanism so as to guarantee the orderly development of various practical activities. The whole process of ideological and political education in the entire environment. All the environmental factors that contribute to the growth of the university's positive energy values, such as the natural environment, institutional environment, humanistic environment, and academic environment in schools, can all serve as an ideological and political education environment for the whole process. The construction and improvement of the campus environment are the most indispensable in the construction of a full range of ideological and political education models. The construction of the campus environment can bring powerful advancement to the ideological and political education process. To follow the principle of ideological and political education in all aspects of the whole process, its pattern must have three characteristics: strong academic nature, noble morality, and abundant ideology.

\section{Conclusion}

Ideological and political education is a specific practical activity that deals with the relationship between people and people, between people and society, and to solve people's ideological and social issues. The Problem of Students' Ideological and Political Education Performance Evaluation. In the theoretical community, academic studies involving the assessment of ideological and political education models of college students have become less frequent. In practical work, the current general practice of combining quantitative assessment with mass assessment has many problems in both validity and reliability, and Operation is also very difficult. Therefore, the research on the evaluation of the ideological and political education performance has yet to be furthered by the scholars.

\section{References}

[1] Xinxin Yang. An Analysis of the Ideological and Political Education Mode of College Students J. Higher Education Research in China, 2005, (3); 68- 69.

[2] Zhang Yu, Zhang Zaixing. University network information environment and ideological and political education model construction J. Ideological and Theoretical Education, 2006, (3); 23- 31.

[3] Wu Yiqiao. Exploration of the New Mode of Ideological and Political Education Network in Colleges. J. Higher Engineering Education Research, 2003, (4); 65- 88.

[4] Wang Yong's Comprehensive Management Model of Ideological and Political Education in Colleges J. Coal Higher Education, 1997, (3); 37- 38.

[5] Jiang Renping. Research on the ideological and political education model under the new situation J. Research on Ideological and Political Education, 1997, (4); 4- 5. 